\title{
Effect of Magnesium-Based Coatings on Titanium or Zirconia Substrates on Bone Regeneration and Implant Osseointegration- A Systematic Review
}

\author{
Ahmad H Almehmadi * \\ Faculty of Dentistry, Oral Biology Department, King Abdulaziz University, Jeddah, Saudi Arabia
}

Magnesium (Mg) is an essential trace element that has a significant role in the human body through its effects on bone metabolism. It has various applications in orthodpaedics and dentistry and the interest of this systematic review lies in its potential role as a dental implant surface coating. The dental implants can fail at different stages starting with its osseointegration phase to the restorative stage in the oral cavity. The biological loss of

OPEN ACCESS

Edited by:

Kumar Chandan Srivastava,

Al Jouf University, Saudi Arabia

Reviewed by:

Shivasakthy Manivasakan,

Sri Balaji Vidyapeeth University, India

Ritika Bhambhani,

Guru Nanak Institute of Dental

Sciences and Research, India

*Correspondence:

Ahmad H Almehmadi

ahalmehmadi@kau.edu.sa

Specialty section:

This article was submitted to Biomaterials,

a section of the journal

Frontiers in Materials

Received: 06 August 2021 Accepted: 19 October 2021 Published: 01 November 2021

Citation: Almehmadi AH (2021) Effect of Magnesium-Based Coatings on

Titanium or Zirconia Substrates on Bone Regeneration and Implant

Osseointegration- $A$

Systematic Review.

Front. Mater. 8:754697.

doi: 10.3389/fmats.2021.754697 bone integration to the implant surface has been classified as one of the primary reasons for dental implant failure. There have been numerous strategies that have been shown to compensate this reason for implant failure, among which are the dental implant surface coatings. These coatings have been shown to improve the enhance the adhesion as well as the process of osseointegration. There are numerous studies in the existing literature that have analyzed the effects of Mg-based coatings on cellular as well as biological processes in bone-implant integration. A systematic search of various databases yielded 175 articles, of which 14 in vitro and experimental animal studies that analyzed the effect of Mg-based coatings and compared it to other coatings or no surface coatings were included in this systematic review. The main outcomes of this systematic review have been cellular behavior, osseointegration, and osteogenic markers and the effects of Mg-based coatings in these parameters have been highlighted in this review.

Keywords: magnesium, dental implant surface coating, osseointegration, osteogenic markers, hydroxyapatite

\section{INTRODUCTION}

Titanium (Ti) and its alloys have become the mainstay biomaterials for dental implants for their mechanical properties and excellent biocompatibility. But, these metals can get corroded in a biological environment and toxic reactions may occur (Tschernitschek et al., 2005; Niinomi, 2008). Zirconia (Zir) implants were extensively used for their increased corrosion resistance, good biocompatibility, favorable esthetic and good mechanical properties. Even though both materials have load-bearing applications with their unique properties, the main challenge in implant dentistry remains to be osseointegration. Dental implants of both metal and ceramic materials are prone to failure due to insufficient integration to bone. It may result in the formation of a fibrous tissue or weak bone formation that may cause infections or unstable implants prone to surgical removal (Best et al., 2008; Liang et al., 2007; Brohede et al., 2009). 
In present day implantology, osseointegration is wellresearched and predictable but it is also reliant on the case selection and the surgical procedure or loading protocol based on the stage of failure despite the successful clinical outcomes of dental implants (Albrektsson, 1998). The literature suggests that there are two mechanisms by which surface modifications on implants can influence osseointegration and they include: 1) biomechanical interlocking where there is bone growth into the rough surface of the implant and 2) biochemical interaction and bonding at the tissue-implant junction (Albrektsson and Wennerberg, 2004). For enhanced osseointegration, three factors have to be considered and they include 1) Improving macro-retentive features in dental implants such as screw/thread design or solid body press fit, and sintered bead technologies, 2) Improving micro-retentive features such as "surface roughness" of the implant to favor cellular and molecular mechanisms for bone growth along the implant surface, and 3) Surface modification that results in a topography favorable for the differentiation of cells that enable an osseous interface on the surface of implants (Stanford, 2008).

Surface coatings on titanium and zirconia dental implants offer the best approach to improving the rate of implant-bone integration and enhancing adhesion to other materials in restorations. It offers dual benefits with improved micromechanical retention and alteration of the surface chemistry for activation of biological processes that favor bone growth (Ying Kei Lung, 2017). There are various techniques that can be used to generate a surface coating on dental implants and they include plasma spraying, sol-gel processing, grit blasting, sand blasting with acid etching, laser etching, ion implantation and sputtering. There is consistent research with both plasma spraying and acid etching techniques (Jemat et al., 2015). Some of the materials that can be coated on the implant surface include hydroxyapatite (HA), ceramics, calcium phosphate, bioactive glass, and fluoride. Grit blasting and sol-gel techniques promote adhesion to restoration whereas materials like bioactive glass and HA promote osseointegration (Lung and Matinlinna, 2012; CattaniLorente et al., 2010; Hench, 2002; Darimont et al., 2002). The downside of materials like bioactive glass and HA include poor mechanical strength, brittleness, and bacterial infections around implants, so the quest for newer biomaterials is on the rise with research targets on materials having antibacterial activity, improving osseointegration outcomes that in turn can translate into long-term clinical success (Ying Kei Lung, 2017).

The alteration of implant surface chemical characteristics comprises a more significant approach in improving the biological activity of dental implants and trace elements like calcium, zinc, silicon, magnesium, and strontium have been commonly used as surface coatings for dental implants (Sawada et al., 2013; Hass et al., 2012; Yu et al., 2013; Park et al., 2010; Shi et al., 2012). Various studies have shown their positive influence on osteoblastic activity and enhance bone growth along with improved bone healing (Boanini et al., 2010; Castellani et al., 2011; Hoppe et al., 2011). Magnesium $(\mathrm{Mg})$ is the fourth most abundant cation in the human body and with the total physiologic $\mathrm{Mg}$, half of it being stored in mineralized bone tissue (Staiger et al., 2006). Magnesium has been shown to play a critical role in bone metabolism and it can interact with integrins on the surface of osteoblasts, thereby promoting its cell stability and adhesion properties (Zreiqat et al., 2002; Yamasaki et al., 2002).

There are numerous studies in the existing literature that have shown the effects of magnesium coatings on titanium or zirconia implants but there is a lack of a systematic approach towards the reporting of its properties with respect to cell bioactivity, osseointegration, or bone regeneration. Thus, the aim of this systematic review was to collate the evidence on magnesium coatings on titanium or zirconia implants, comparisons with conventional or no surface coatings, and to analyze its effects on outcomes like cell behavior, osseointegration, and markers of osteogenesis.

\section{MATERIALS AND METHODS}

According to the Preferred Reporting Items for Systematic Reviews and Meta Analyses (PRISMA) guidelines, the focused question was constructed in the Population Intervention Control Outcomes (PICO) format and it was What is the effect of magnesium-based coatings in $\mathrm{Ti}$ or Zir implants on osseointegration, bioactivity, and markers of osteogenesis.

\section{Literature Search}

A combination of keywords like "dental implant", "magnesium", "implant coatings, and "osseointegration" were used in an electronic search in databases like Pubmed/Medline, Embase, Google Scholar, and Cochrane library. The search was performed using the PICO format and it was performed individually for the keywords and combined with "and" and "or" terms.

Pubmed/Medline: Search: (dental implant) or (titanium implant) or (zirconia implant) or (Ti dental implant) or (dental implant surface coating) or (surface coating) and (magnesium) or (magnesium oxide) or (magnesium carbonate) or (magnesium fluoride) or (magnesium based surface coating) and (ceramics) or (bioactive glass) or (fluoride) or (ceramics) or (hydroxyapatite) or (calcium phosphate) and (cell adhesion) or (cell proliferation) or (cell differentiation) or (bioactivity) or (osteoblast) or (fibroblast) or (osseointegration)

A manual search was performed to include articles that were relevant to the topic of the systematic review. The bibliographies from the full-texts of the articles were manually searched for relevant articles to be included in this review. The search timeline included articles where the focus question was addressed and it was between the years 2000 and 2019.

\section{Eligibility Criteria}

This systematic review aimed to analyze the effects of magnesium-based implant coatings on osseointegration and bone regeneration at cellular level, so animal and in vitro studies were included in the search along with studies that were conducted in humans that had observed the desired 
FLOW CHART OF INCLUSION OF STUDIES IN THE SYSTEMATIC REVIEW PROCESS

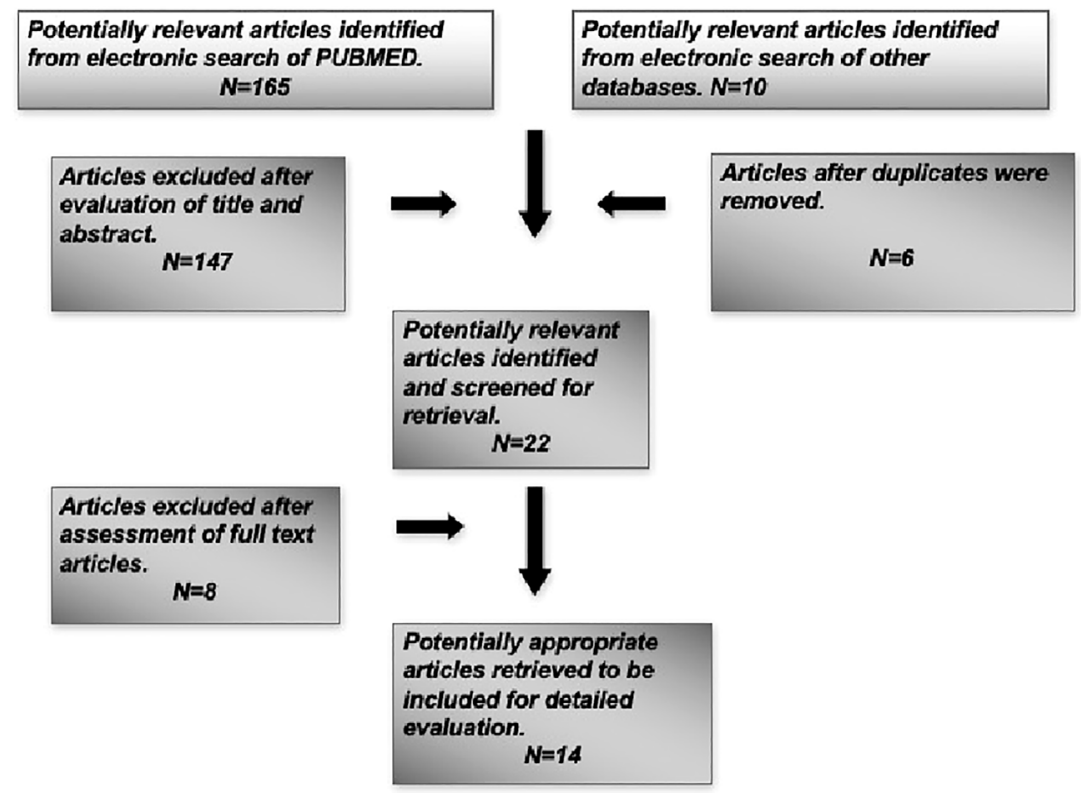

FIGURE 1 | Flowchart of search methodology and inclusion of studies in the systematic review.

outcomes. Only articles published in English language were included in this review. The exclusion criteria included articles which had no relevance to dentistry and only to orthopedic applications, reviews, and letters to the editor. Also, articles that observed the outcome measures in non-titanium materials like magnesium implants and the coatings were excluded from this review. The focused question was used to analyze the included studies and the relevant information on outcome measures were extracted. A flowchart has been depicted on the search methodology employed in this systematic review (Figure 1).

\section{Data Extraction}

Two independent reviewers (XX, YY) conducted the literature search employing the keywords and MeSh terms, following which the articles were analyzed based on the eligibility criteria. If there was disagreement on the inclusion of certain articles, a discussion was held to resolve it. In instances where a study did not report raw data relevant to the outcome measures, the data was extracted from either the tables or graphical representations in the study. The corresponding authors were contacted to solve doubts or provide missing information relevant to the systematic review. The data extraction tables have been attached (Supplementary file).

\section{Risk of Bias Assessment of Included Studies}

The quality assessment for each animal study was carried out using the SYRCLE's RoB tool that has 10 items and two independent authors (XX, YY) performed risk assessment across the following categories: Sequence generation, allocation concealment, blinding of investigators and outcome assessors, random housing for animals, selective reporting of outcome measures, addressing incomplete outcome, and other potential risks for bias. The risk was categorized either as "high-risk", "lowrisk" or "unclear risk" (Hooijmans et al., 2014). A third independent author (ZZ) resolved any disagreements on risk assessment with a discussion. In the existing literature, there are no tools or indices for the validation of in vitro studies and the risk of bias is quite low due to its position in the hierarchy of evidence-based dentistry (Richards, 2009).

\section{RESULTS}

\section{Search Results}

The systematic search of the literature yielded a total of 175 articles of which 22 articles were identified to be satisfying the eligibility criteria. The manual search of relevant journals and bibliography yielded two articles that were included in this systematic review. Some articles were excluded after full text assessment and a total of 14 articles were included for evaluation in this review. Among the included articles, nine were in vitro studies (Gorrieri et al., 2006; Jiang et al., 2014; Mihailescu et al., 2016; Onder et al., 2018; Pardun et al., 2015; (Park et al., 2013; Won et al., 2017; Yu et al., 2017; Xie et al., 2009), four experimental animal models (Sul et al., 2006; Cho et al., 2010; Li et al., 2014; Tao et al., 2016) and one study was part animal model and part in vitro design (Zhao et al., 2013). The characteristics and the main outcome measures of the included studies have been shown in (Table 1). 
TABLE 1 | Characteristics and Main outcome of Included Studies.

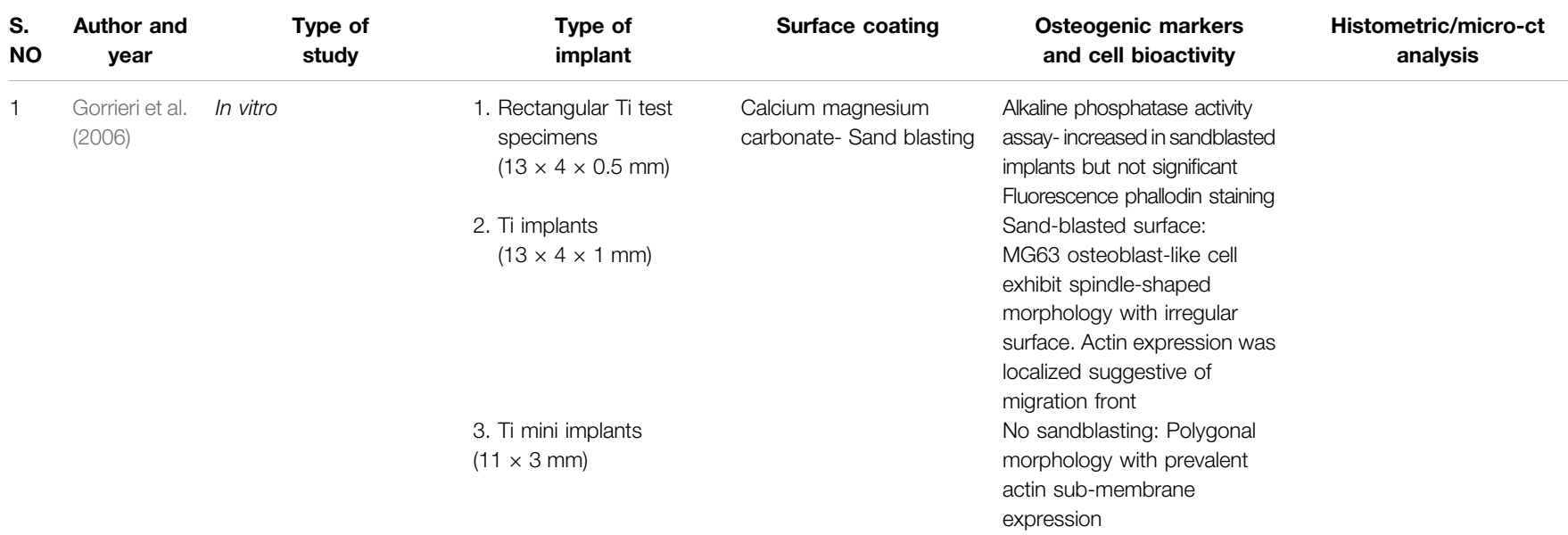

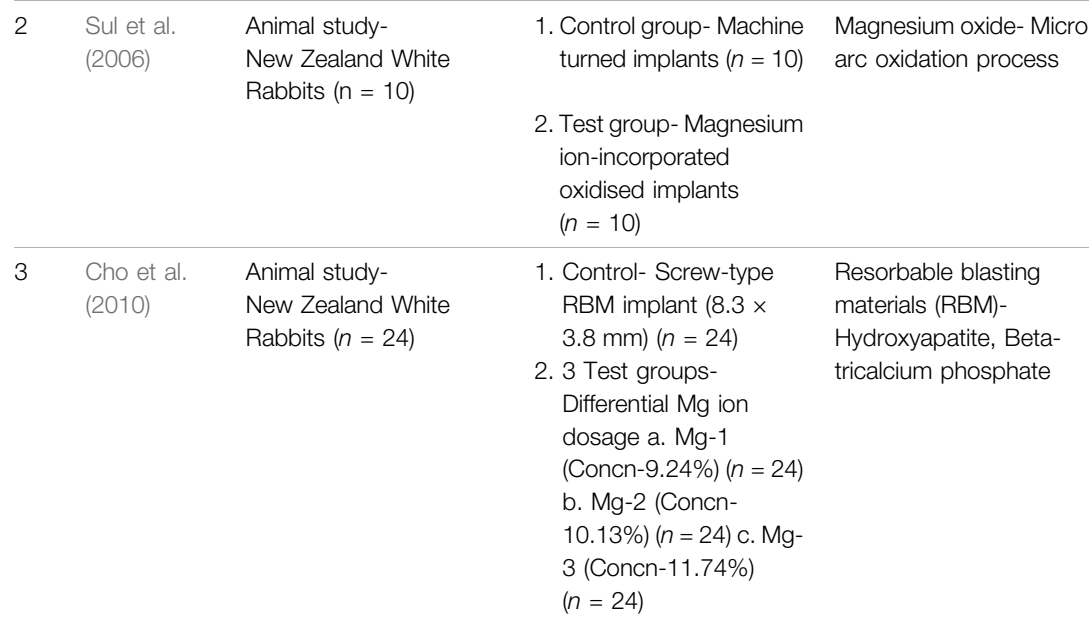

Osseointegration speed between 3 and 6 weeks: Test Mg implants- $2.5 \mathrm{Ncm} /$ week Control Machine turned implants- $2.0 \mathrm{Ncm} /$ week (p-value<0.005)

$(n=10)$ 
TABLE 1 | (Continued) Characteristics and Main outcome of Included Studies.

\begin{tabular}{|c|c|c|c|c|c|c|}
\hline $\begin{array}{l}\text { S. } \\
\text { NO }\end{array}$ & $\begin{array}{c}\text { Author and } \\
\text { year }\end{array}$ & $\begin{array}{l}\text { Type of } \\
\text { study }\end{array}$ & $\begin{array}{l}\text { Type of } \\
\text { implant }\end{array}$ & Surface coating & $\begin{array}{l}\text { Osteogenic markers } \\
\text { and cell bioactivity }\end{array}$ & $\begin{array}{c}\text { Histometric/micro-ct } \\
\text { analysis }\end{array}$ \\
\hline 5 & $\begin{array}{l}\text { Li et al. } \\
\text { (2014) }\end{array}$ & $\begin{array}{l}\text { Animal study- } \\
\text { Ovariectomized rats } \\
(n=18)\end{array}$ & $\begin{array}{l}\text { 1. Rod-shaped Ti implants } \\
(12 \times 1.1 \mathrm{~mm})(n=36) \text { and } \\
\text { Ti discs (Diameter-9 mm) } \\
(n=12) \text { a. Magnesium- } \\
\text { incorporated HA (MgHA) } \\
\text { coating b. HA coating }\end{array}$ & $\begin{array}{l}\mathrm{MgHA} \text { ) and } \mathrm{HA} \text { coating } \\
\text { on implant using Sol-gel- } \\
\text { dip-coating method }\end{array}$ & & $\begin{array}{l}\text { Bone Area ratio a. } \mathrm{MgHA}= \\
36.76 \% \text { b. } \mathrm{HA}=27.26 \% \\
(p<0.01) \\
\text { Bone implant contact a. } \\
\mathrm{MgHA}=52.57 \% \text { b. } \mathrm{HA}= \\
34.06 \%(p<0.01) \\
\text { Micro-CT analysis } \\
\text { Trabecular bone architecture } \\
\text { and osseointegration was } \\
\text { significantly improved with } \\
\text { MgHA compared to HA } \\
\text { group }\end{array}$ \\
\hline 6 & $\begin{array}{l}\text { Mihailescu } \\
\text { et al. (2016) }\end{array}$ & In vitro study & $\begin{array}{l}\text { 1. Bovine derived } \mathrm{HA} \\
(\mathrm{BHA}) \text { coating } \\
\text { 2. } \mathrm{BHA}: \mathrm{MgF} 2 \\
\text { 3. } \mathrm{BHA}: \mathrm{MgO}\end{array}$ & $\begin{array}{l}\text { MgF2 or MgO- Pulsed } \\
\text { laser deposition }\end{array}$ & $\begin{array}{l}\text { Epithelial cells type } 2 \text { (HeP-2). } \\
\text { Cell viability: Human Genes of } \\
\text { arrestin beta } 1 \text { (ARRB1), } \\
\text { mannosidase alpha class 2B } \\
\text { (MAN2B1), and transient } \\
\text { receptor potential channel } 1 \\
\text { (TRPC1) expression } \\
\text { increased in the following } \\
\text { order: BHA > BHA:MgF2 } \\
\text { >BHA:MgO. Antimicrobial } \\
\text { activity BHA:MgO and BHA: } \\
\text { MgF2 exhibit } 4 \text { times higher } \\
\text { anti-bacterial activity against } \\
\text { the tested strains: } \\
\text { Enterococcus sp. Candida } \\
\text { albicans Micrococcus sp }\end{array}$ & \\
\hline 7 & $\begin{array}{l}\text { Onder et al. } \\
(2018)\end{array}$ & In vitro study & $\begin{array}{l}\text { 1. Titanium Grade II plates } \\
\text { a. Low (Mg < } 10 \text { at } \% \text {; } \mathrm{ML} \\
\text { b. High (Mg }>10 \text { at\%; MgL } \\
\text { 2. Ti plates }\end{array}$ & Mg- Arc-PVD technique & $\begin{array}{l}\text { Rat bone-marrow-derived } \\
\text { stem cells Cell proliferation: All } \\
\text { surfaces supported cell } \\
\text { attachment and proliferation } \\
\text { and it was observed on day } \\
\text { 1,5, and } 8 \text {. Cell numbers } \\
\text { increased on all the surfaces for } \\
\text { first } 5 \text { days. At day } 8 \text {, cell } \\
\text { numbers decreased in Ti and } \\
\text { TiN, whereas it continued to } \\
\text { remain constant or increased for } \\
\text { magnesium doped Ti implants } \\
\text { Collagen deposition: More } \\
\text { Type I collagen was deposited } \\
\text { on TiN and Mg-doped } \\
\text { implants (Low). The } \\
\text { deposition decreased when } \\
\text { Mg content was increased. } \\
\text { ALP activity At day } 5 \text {, activity } \\
\text { was lowest with Ti implants } \\
\text { and highest on Mg-doped Ti } \\
\text { implants (Low). Mg-doped Ti } \\
\text { implants (High) ALP activity } \\
\text { was significantly lower than } \\
\text { that of the low counterpart at } \\
\text { day } 5 \\
\text { Cell density and } \\
\text { mineralization: Higher on Mg } \\
\text { containing surfaces. Calcium } \\
\text { deposition: Was higher with } \\
\text { Mg-containing surfaces }\end{array}$ & \\
\hline
\end{tabular}


TABLE 1 | (Continued) Characteristics and Main outcome of Included Studies.

\begin{tabular}{lccccc}
\hline S. & $\begin{array}{c}\text { Author and } \\
\text { Noar }\end{array}$ & $\begin{array}{c}\text { Type of } \\
\text { study }\end{array}$ & $\begin{array}{c}\text { Type of } \\
\text { implant }\end{array}$ & Surface coating & $\begin{array}{c}\text { Osteogenic markers } \\
\text { and cell bioactivity }\end{array}$ \\
\hline
\end{tabular}

8 Pardun et al. In vitro study (2015)
1. Yttria-stabilized zirconia $\mathrm{MgO}$ or MgF2-Wet and $\mathrm{HA}$ incorporated with powder spraying $\mathrm{MgO}$ or $\mathrm{MgF} 2$

2. TZCP, Thermanox-

Reference samples
Human osteoblasts (HOB)

Cell proliferation: Higher in Mg-coatings with constant increase of formazan over 9 days. Reference samples had the lowest activity Cell differentiation: ALP activity was increased in all samples and it was reduced in TZCP and increased in Thermanox. Cell growth, morphology, and spreading. TZCP- round morphology

Thermanox- Flat and extensively spread. Mgcontaining coating- Flat cells and spread extensively. Highest cell viability, ALP activity, and cell number in Thermanox. Similar results in Mg-containing surfaces

\section{Park et al. In-vitro} (2013)
1. Titanium-Grade $\|$ discs (12 mm, 25 mm diameter/ $1 \mathrm{~mm}$ thickness) a. TiSNon-coated Ti surface b. Ti-Mg- Ti coated with Mg c. Ti-MgHA- Ti surface coated with $\mathrm{Mg}$ and $\mathrm{HA}$.
Mg coating- Direct current magnetron sputtering. MgHARadiofrequency magnetron sputtering
Mouse MC3T3-E1 cells Cell proliferation: Ti-Mg and Ti-MgHA had higher proliferation rate of 112 and $124 \%$ respectively when compared to Ti-S $(p>0.05)$ ALP activity: Cells on Ti-Mg and Ti-MgHA showed 50-60\% higher ALP activity than those on Ti-S $(p<0.05)$ Osteogenic markers: Bone sialoprotein (BSP)- mRNA expression increased 1.8 and 2.1-fold in Ti-Mg and Ti-MgHA respectively. Osteocalcin (OCN) mRNA expression increased 1.5 and 1.4-fold in Ti-Mg and Ti-MgHA respectively BSP and OCN expression more than Ti-S surface Extracellular matrix: COL-I gene: There was expression of this gene in both Ti-Mg and Ti-MgHA surfaces
1. Titanium implants $(20 \times$ Electrochemical $1 \mathrm{~mm})$ a. Pure HA coating deposition for coatings b. HA incorporated with $10 \%$ Zinc, Mg, and Strontium. i) ZnHA ii) $\mathrm{MgHA}$ iii) SrHA
Animal study- Spraque
Dawley rats $(n=50)$ a.
Ovariectomy $(n=45) b$
Sham operation (n-5)

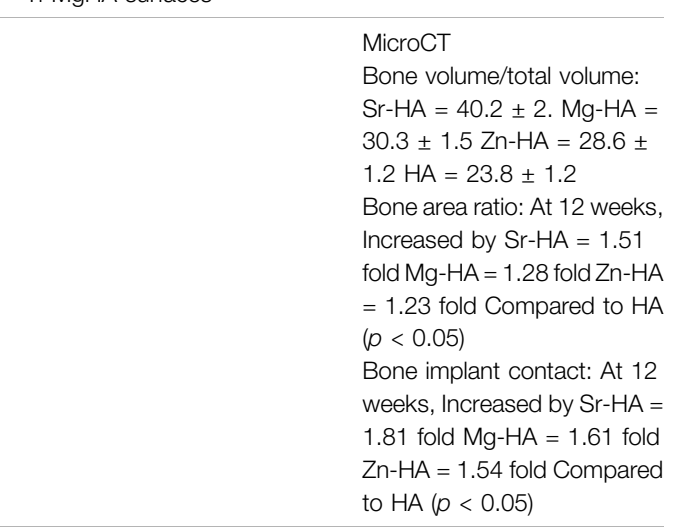

(Continued on following page) 
TABLE 1 | (Continued) Characteristics and Main outcome of Included Studies.

\begin{tabular}{|c|c|c|c|c|c|c|}
\hline $\begin{array}{l}\text { S. } \\
\text { NO }\end{array}$ & $\begin{array}{c}\text { Author and } \\
\text { year }\end{array}$ & $\begin{array}{l}\text { Type of } \\
\text { study }\end{array}$ & $\begin{array}{l}\text { Type of } \\
\text { implant }\end{array}$ & Surface coating & $\begin{array}{l}\text { Osteogenic markers } \\
\text { and cell bioactivity }\end{array}$ & $\begin{array}{c}\text { Histometric/micro-ct } \\
\text { analysis }\end{array}$ \\
\hline 11 & $\begin{array}{l}\text { Won et al. } \\
(2017)\end{array}$ & In vitro study & $\begin{array}{l}\text { 1. Titanium Surfaces a. } \\
\text { Resorbable Blast Media } \\
\text { (RBM) b. Ca-ion implanted } \\
\text { surface c. Mg-ion } \\
\text { implanted surface }\end{array}$ & $\begin{array}{l}\text { Plasma immersion ion } \\
\text { implantation method }\end{array}$ & $\begin{array}{l}\text { Human bone marrow } \\
\text { Mesenchymal stem cells } \\
\text { (hBM-MSC) } \\
\text { Cell attachment morphology } \\
\text { Mg-ion implanted surface- } \\
\text { Flattened morphology with } \\
\text { wide extracellular membrane } \\
\text { bridge compared to RBM. } \\
\text { Ca ion-implanted surface- } \\
\text { More extended filopodia } \\
\text { compared to RBM and Mg- } \\
\text { ion implanted surface } \\
\text { Cell proliferation } \\
\text { Cell proliferation on all surfaces } \\
\text { significantly increased but } \\
\text { there was no difference } \\
\text { between three surfaces } \\
\text { Osteogenic differentiation } \\
\text { RUNX-2-Higher expression in } \\
\text { Mg-ion implanted surface } \\
\text { COL-Type I: Higher } \\
\text { expression in Mg-ion } \\
\text { implanted surface } \\
\text { OCN: Lower in Ca-ion implanted } \\
\text { surface compared to RBM and } \\
\text { Mg-ion implanted surface } \\
\text { ALP activity: Higher in RBM } \\
\text { surface }\end{array}$ & \\
\hline
\end{tabular}

12 Xie et al. In vitro study (2009)
1. Titanium alloy cylinders $(25.4 \times 25.4 \mathrm{~mm})(n=2)$ a. Magnesium silicate (MS) coating. b. Grit blasted and roughened-HA
MS coating- Plasma spraying method

Canine bone marrow stem

cells

Cell adhesion and

morphology

Polygonal shape with cytoplasmic processes adhering to coated surface.

They spread to reach larger sizes on the coating with compact bodies and short cellular extensions. Cells were closely adherent to coated surface

Cell proliferation

Number of cells increased with culture time and similar to that of HA coating ALP activity Remained high whereas HA coating surface began to decrease. MSC's on MS coating had higher differentiation level compared to those of HA.

13 Yu et al. In vitro study

1. Titanium plates $(10 \times 10 \quad \mathrm{Zn} / \mathrm{Mg}$ ion co-implanted $\times 1 \mathrm{~mm} ; 20 \times 20 \times 1 \mathrm{~mm}) \quad$ Ti- Plasma ion 2. Titanium cylinders $(2 \times$ $7 \mathrm{~mm}$ ) a. Zn/Mg PIII b. Znimplantation method

PIII C. Mg-PIII d. Ti

Rat bone marrow

Mesenchymal stem cells (BMSC's): Cell density and morphology: Increased cell density and filopodia extension in Zn/Mg PIII $\rightarrow$ can promote initial adhesion and spreading. Zn/Mg PIII $\rightarrow$ Can upregulate integrin-alpha1 and integrin-beta1 than ZnPIII and MgPIII. 
TABLE 1 | (Continued) Characteristics and Main outcome of Included Studies.

\begin{tabular}{lccccc}
\hline S. & $\begin{array}{c}\text { Author and } \\
\text { NO }\end{array}$ & $\begin{array}{c}\text { Type of } \\
\text { study }\end{array}$ & $\begin{array}{c}\text { Type of } \\
\text { implant }\end{array}$ & Surface coating & $\begin{array}{c}\text { Osteogenic markers } \\
\text { and cell bioactivity }\end{array}$ \\
\hline
\end{tabular}

Cell viability: Higher with Zn/

MgPIII. Osteogenic markers:

RUNX-2, OCN, OPN, ALP was

higher with $\mathrm{Zn} / \mathrm{MgPIII}$.

Concomitant protein levels of

ALP, OCN were significantly

enhanced than other three

surfaces. Human Umblical Vein

Endothelial cells (HUVECs) Zn/

MgPIII and MgPIII improved the

viability of HUVECs

Zn/MgPIII Increased

expression of VEGF (Vasuclar

endothelial growth factor) and

KDR (kinase domain receptor)

with increased protein

expression of Hypoxia-

inducible factor (HIF-1alpha)

Antibacterial: $P$ gingivalis, $F$

nucleatum, Strep. Mutans. Zn/

MgPIII and ZnPIII surfaces had

the highest inhibitory rates with

bacteria counting method

compared to MgPIII. $(p<0.01)$

$\begin{array}{ll}\text { Zhao et al. } & \text { In vitro study and Animal } \\ \text { (2013) } & \text { study New Zealand } \\ & \text { White Rabbits }(n=15)\end{array}$

White Rabbits ( $n=15$ )

$\begin{array}{ll}\text { 1. Screw titanium implants } & \text { Pure hydroxyapatite } \\ (8 \times 4.1 \mathrm{~mm})(n=30) 2 . & (\mathrm{EDHA}) \text { or Mg-substituted } \\ \text { Titanium plates }(25 \mathrm{~mm} \times & \mathrm{HA}(\mathrm{EDMHA})- \\ 1.5 \mathrm{~mm})(n=12) ;(10 \times 10 & \text { Electrochemical } \\ \times 1 \mathrm{~mm})(n=72) \text { a. EDHA } & \text { deposition } \\ \text { coatingb. EDMHA coating } & \end{array}$

coatingb. EDMHA coating
Mouse MC3T3-E1

preosteoblasts

Cell growth

Significantly more viable cells

were found on EDMHA

coated surface than EDHA

$(p=0.02)$ at 7 days of culture

ALP activity

EDMHA group: $0.78 \pm$

$0.13 \mathrm{nmol} / \mu \mathrm{g} / \mathrm{h}$

EDHA

$0.41 \pm 0.1 \mathrm{nmol} / \mu \mathrm{g} / \mathrm{h}(p=$

0.004)

OCN levels

EDMHA group: $116.42 \pm$

$7.64 \mathrm{ng} / \mathrm{mg}$

EDHA

$94.7 \pm 13.1 \mathrm{ng} / \mathrm{mg}(p=0.004)$
Bone implant contact (\%) At 2 weeks: EDMHA group: $61.77 \pm 8.53$ EDHA: $44.17 \pm$ 12.35 ( $p=0.086$ ) Bone area (\%) At 2 weeks: EDMHA group: $40.30 \pm 10.67 \mathrm{EDHA}$ : $38.39 \pm 23.25(p=0.831)$

,


TABLE 2 | Summary of results of in vitro studies observed for main outcome measures in Magnesium-based coatings.

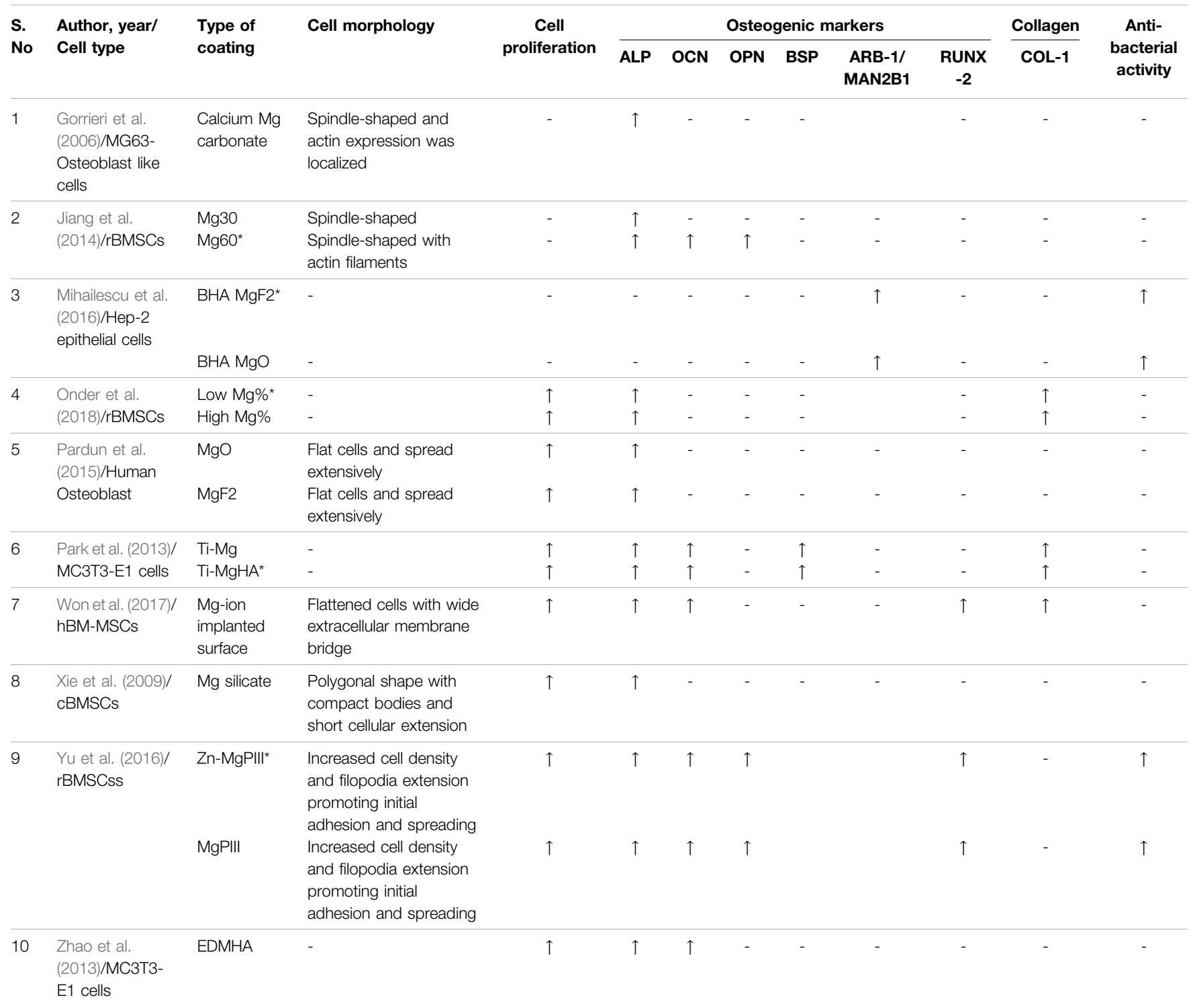

\section{Cellular Proliferation}

In this systematic review, a total of seven out of ten included studies observed the effect of Mg-based coatings on cellular proliferation and found that there was a substantial increase in proliferation in the studied cell-lines. The surface coatings include $\mathrm{MgO}, \mathrm{MgF} 2, \mathrm{MgHA}, \mathrm{Mg}$-ions, $\mathrm{Zn}-\mathrm{Mg}$ co-implanted, and magnesium silicate. There was a relatively higher increase in surface coatings that include MgHA, Low Mg concentration, and $\mathrm{Zn}-\mathrm{Mg}$ co-implanted surfaces when compared to their respective control groups (Onder et al., 2018; Pardun et al., 2015; Park et al., 2013; Won et al., 2017; Yu et al., 2017; Xie et al., 2009; Zhao et al., 2013).

\section{Osteogenic Markers}

All the included studies in the systematic review observed the expression of osteogenic markers using polymerase chain reaction and the markers include: 1) alkaline phosphatase
(ALP), osteocalcin (OCN), Osteopontin (OPN), bone sialoprotein (BSP), arrestin beta-1 (ARB-1), mannosidase alpha class-2B (MAN2B-1), and runt-related transcription factor-2 (RUNX-2). The observed osteogenic markers were significantly elevated with the Mg-based coatings analyzed in the respective studies (Gorrieri et al., 2006; Jiang et al., 2014; Mihailescu et al., 2016; Onder et al., 2018; Pardun et al., 2015; Park et al., 2013; Won et al., 2017; Yu et al., 2017; Xie et al., 2009; Zhao et al., 2013).

\section{Collagen Deposition}

In three in vitro studies, the deposition of collagen type-I was significantly increased with Ti-Mg, MgHA, Mg-ion implanted surfaces with varying concentrations. There was significant increase with Low $\mathrm{Mg} \%$ (9.24\%) when compared to High $\mathrm{Mg}$ $\%$, and also in Mg-HA group on comparison with $\mathrm{Ti}-\mathrm{Mg}$ group (Onder et al., 2018; Park et al., 2013; Won et al., 2017). 


\section{Anti-Bacterial Activity}

Two in vitro studies observed the anti-bacterial effect of $\mathrm{Mg}$ based coatings with one study examining bovine-derived HA (BHA) with $\mathrm{MgO}$ or $\mathrm{MgF} 2$ and the other study observing $\mathrm{Mg}$ and $\mathrm{Zn}-\mathrm{Mg}$ co-implanted Ti surfaces. Yu et al., showed that $\mathrm{Zn}-\mathrm{Mg}$ co-implanted surfaces had the highest antibacterial effect against microbes like Porphyromonas gingivalis, Fusobacterium nucleatum, and Streptococcus mutans when compared to only Mg-incorporated surfaces ( $\mathrm{Yu}$ et al., 2017). Mihailescu et al., observed that both BHA:MgO and BHA:MgF2 had 4 times higher inhibitory activity against strains of Enterococcus sp, Micrococcus sp, and Candida albicans (Mihailescu et al., 2016).

\section{Animal Experiments}

In the animal-model experimental study conducted by Sul et al., on NZ white rabbits, the osseointegration speed was compared between $\mathrm{Mg}$-ion incorporated oxidized implants and non-coated machine turned implants. There was highly significant difference in the speeds between the test and Mg-ion groups at 3 and 6 weeks with $p$-value $<0.005$ and also notable differences in the strengths favoring the Mg-ion group during the same follow-up intervals (Sul et al., 2006). Cho et al., observed the effects of differential concentrations of Mg-ions as surface coating and observed that Mg-1 implants (Mg concentration-9.24\%) had the highest removal torque values (RTQ) when compared to the other groups as well as the highest bone-implant contact (BIC) values, bone fill area, and new bone formation when compared to the other groups in the study (Cho et al., 2010).

The other animal studies $(n=3)$ observed the incorporation of $\mathrm{Mg}$ to hydroxyapatite (HA) on titanium surfaces either using solgel-dip coating method or electrochemical deposition ( $\mathrm{Li}$ et al., 2014); (Tao et al., 2016); (Zhao et al., 2013). In all the studies, the control group was pure HA coating whereas one study compared Mg-based coating with HA incorporated with other elements like Zinc (Zn) and Strontium (Sr) (Tao et al., 2016). The analyzed results observed that bone area ratio and BIC values were significantly higher for $\mathrm{Mg}-\mathrm{HA}$ coating when compared to pure HA titanium surface (Li et al., 2014); (Tao et al., 2016); (Zhao et al., 2013). A micro-CT analysis also observed that trabecular bone structure and osseointegration was significantly improved with Mg-HA coating Li et al., 2014; Tao et al., 2016; Zhao et al., 2013). Li et al., observed during biomechanical testing that $\mathrm{Mg}-\mathrm{HA}$ coating increased the interfacial shear strength and maximum push-out force when compared to HA coatings (Li et al., 2014). Tao et al., observed some slightly improved results with Sr-HA when compared to $\mathrm{Mg}-\mathrm{HA}$ in terms of BIC values, bone volume, and bone area ratio (Tao et al., 2016). The summary of results from the animal studies have been tabulated in (Table 3 ).

\section{Risk of Bias Assessment}

In this systematic review, all experimental animal studies were subjected to SYRCLE's RoB tool for assessing the risk of bias. For each domain in the risk assessment tool, the risk of bias for each study has been summarized in (Figure 2). The 10 risks of bias items belonging to the risk assessment tool have been presented as percentages for all the included experimental studies
(Figure 3). The studies presented with relatively higher risk of bias for random sequence generation, allocation concealment and blinding whereas the randomization and blinding of outcome assessments, selective reporting of outcome data, and other potential bias were poorly described in the studies. A significantly lower risk of bias was observed for reporting of baseline characteristics and reporting of incomplete outcome data among the included studies.

\section{DISCUSSION}

One of the essential trace elements for both animals and humans is $\mathrm{Mg}$ due to its influence on physiologic activities and bone metabolism. The deficiency of $\mathrm{Mg}$ in the diet can cause reduced bone mass and deranges the mineral and bone metabolic pathways in rats (Rude et al., 2006). In the ideal scenario, biomaterials must influence the proliferation and differentiation of the targeted cell types to stimulate formation of functional tissue (Sader et al., 2009). In the existing literature, there have been studies that show the positive effect of $\mathrm{Mg}$ incorporation into $\mathrm{Ti}$ implants with stimulated bone formation and osseointegration (Revell et al., 2004; Pang et al., 2014). There are some lacunae in research that can show the cumulative effects of $\mathrm{Mg}$ as surface coating on dental implants. Thus, in this systematic review, the focused question was the effect of various $\mathrm{Mg}$-based coatings on Ti or Zir implants in terms of cell behavior, osteogenic markers, and on the process of osseointegration.

A total of 14 studies of both in vitro and experimental animal model design were included in this review based on the eligibility criteria. The results from the animal models were based on histologic or micro-CT analysis and observations were made in relation to bone-related parameters and osseointegration. It was shown that Mg-based coatings significantly increased the BIC values, bone area ratio, and bone volumes as well as improved speed of osseointegration and higher RTQ values (Sul et al., 2006; Cho et al., 2010; Li et al., 2014; Tao et al., 2016; Zhao et al., 2013). The process of osseointegration is reflected based on the evolution of bone growth and integration in the peri-implant tissues (Yu et al., 2016). It is well known that bone formation and integration are quantitatively measured in terms of BIC and bone area and BIC values are known to have a strong association with the strength of the bone-implant surface (Yu et al., 2016; Zhou et al., 2008). It is pivotal to note the superior bone contact observed in Mg-based coatings on $\mathrm{Ti} / \mathrm{Zir}$ surfaces when compared to other observed surface coatings such as Resorbable Blasting Materials (RBM-HA, Beta-tricalcium phosphate), HA, ZnHA or groups with no implant surface coating (Sul et al., 2006; Cho et al., 2010; Li et al., 2014; Tao et al., 2016; Zhao et al., 2013).

The role of BMSCs (osteoblast precursor) and osteoblast cells cannot be emphasized more as their initial adhesion and subsequent proliferation can have a direct effect on cellular functionality and the process of osseointegration (Jiang et al., 2013). From the in vitro studies, it was observed that the cells were flattened or spindle-shaped with cellular extensions that facilitate 
TABLE 3 | Summary of results of animal models observed for main outcome measures.

\begin{tabular}{|c|c|c|c|c|c|}
\hline $\begin{array}{l}\text { S. } \\
\text { NO }\end{array}$ & Author & Materials & Groups & Surface coating & $\begin{array}{c}\text { MICRO-CT/HISTOMETRIC } \\
\text { analysis }\end{array}$ \\
\hline 1 & $\begin{array}{l}\text { Sul et al. } \\
(2006)\end{array}$ & $\begin{array}{l}\text { Animal study- New Zealand } \\
\text { White Rabbits }(n=10)\end{array}$ & $\begin{array}{l}\text { 1. Control group- Machine turned } \\
\text { implants }(n=10) \\
\text { 2. Test group- Magnesium ion- } \\
\text { incorporated oxidised implants }(n=10)\end{array}$ & $\begin{array}{l}\text { Magnesium oxide- Micro-arc } \\
\text { oxidation process }\end{array}$ & $\begin{array}{l}\text { Osseointegration speed between } 3 \text { and } \\
6 \text { weeks: Test Mg implants- } 2.5 \mathrm{Ncm} / \\
\text { week } \\
\text { Control Machine turned implants- } 2.0 \\
\text { Ncm/week ( } p \text {-value<0.005) }\end{array}$ \\
\hline 2 & $\begin{array}{l}\text { Cho et al. } \\
(2010)\end{array}$ & $\begin{array}{l}\text { Animal study- New Zealand } \\
\text { White Rabbits }(n=24)\end{array}$ & $\begin{array}{l}\text { 1. Control- Screw-type RBM implant } \\
(8.3 \times 3.8 \mathrm{~mm})(\mathrm{n}=24) \text { Resorbable } \\
\text { blasting materials }(\mathrm{RBM}) \text { - } \\
\text { Hydroxyapatite, Beta-tricalcium } \\
\text { phosphate } \\
\text { 2. Test groups- Differential Mg ion } \\
\text { dosage a. Mg-1 (Concn-9.24\%) }(\mathrm{n}= \\
\text { 24) b. Mg-2 (Concn-10.13\%) }(\mathrm{n}=24) \\
\text { c. Mg-3 (Concn-11.74\%) }(n=24)\end{array}$ & $\begin{array}{l}\text { Mg-Plasma Source Ion } \\
\text { Implantation Method }\end{array}$ & $\begin{array}{l}\text { Removal Torque value: Mg-1 implants } \\
\text { higher RTQ value when compared to } \\
\text { Mg-2 and control implants. }(p<0.05) \\
\text { Bone-Implant contact values: Highest- } \\
\text { Mg-1 (36.1 } \pm 12.3 \%) \text { Lowest-Mg-2 } \\
(26.2 \% \% \pm 10.1 \%)(p<0.05) \text { Bone Fill } \\
\text { Area: Mg-1 (74.1 } \pm 12.3 \%) \text { Mg-2 } \\
(58.1 \pm 24.1 \%) \text { Mg-3 (72.4 } \pm 11 \%) \\
\text { Control }(63.3 \pm 18.3 \%)(p<0.05) \\
\text { New bone formation: Mg-1 }(510.8 \% \pm \\
167.2 \mu \mathrm{m}) \text { Other groups }(330-370 \mu m) \\
(p=0.109)\end{array}$ \\
\hline 3 & $\begin{array}{l}\text { Li et al. } \\
\text { (2014) }\end{array}$ & $\begin{array}{l}\text { Animal study- Ovariectomized } \\
\text { rats }(n=18)\end{array}$ & $\begin{array}{l}\text { 1. Rod-shaped Ti implants }(12 \times \\
1.1 \mathrm{~mm})(n=36) \text { and Ti discs } \\
\text { (Diameter-9mm) }(n=12) \text { a. } \\
\text { Magnesium-incorporated HA (MgHA) } \\
\text { coating b. HA coating }\end{array}$ & $\begin{array}{l}\text { MgHA) and HA coating on } \\
\text { implant using Sol-gel-dip- } \\
\text { coating method }\end{array}$ & $\begin{array}{l}\text { Bone Area ratio c. } \mathrm{MgHA}=36.76 \% \\
\text { d. } \mathrm{HA}=27.26 \%(p<0.01) \\
\text { Bone implant contact c. } \mathrm{MgHA}= \\
52.57 \% \\
\text { d. } \mathrm{HA}=34.06 \%(p<0.01) \\
\text { Micro-CT analysis } \\
\text { Trabecular bone architecture and } \\
\text { osseointegration was significantly } \\
\text { improved with MgHA compared to HA } \\
\text { group }\end{array}$ \\
\hline 4 & $\begin{array}{l}\text { Tao et al. } \\
(2016)\end{array}$ & $\begin{array}{l}\text { Animal study- Spraque Dawley } \\
\text { rats }(n=50) \text { c. Ovariectomy }(n= \\
45) \text { d. Sham operation }(n-5)\end{array}$ & $\begin{array}{l}\text { 1. Titanium implants }(20 \times 1 \mathrm{~mm}) \text { a. } \\
\text { Pure HA coating b. HA incorporated } \\
\text { with } 10 \% \text { Zinc, Mg, and Strontium. i) } \\
\text { ZnHA ii) MgHA iii) SrHA }\end{array}$ & $\begin{array}{l}\text { Electrochemical deposition for } \\
\text { coatings }\end{array}$ & $\begin{array}{l}\text { MicroCT } \\
\text { Bone volume/total volume } \\
\mathrm{Sr}-\mathrm{HA}=40.2 \pm 2.4 \\
\mathrm{Mg}-\mathrm{HA}=30.3 \pm 1.5 \\
\mathrm{Zn}-\mathrm{HA}=28.6 \pm 1.2 \\
\mathrm{HA}=23.8 \pm 1.2 \\
\text { Bone area ratio } \\
\text { At } 12 \text { weeks, Increased by Sr-HA = } \\
1.51 \text { fold } \\
\mathrm{Mg}-\mathrm{HA}=1.28 \text { fold } \\
\mathrm{Zn}-\mathrm{HA}=1.23 \text { fold } \\
\text { Compared to HA ( } p<0.05) \\
\text { Bone implant contact } \\
\text { At } 12 \text { weeks, Increased by Sr-HA = } \\
1.81 \text { fold } \\
\text { Mg-HA = 1.61 fold } \\
\mathrm{Zn}-\mathrm{HA}=1.54 \text { fold } \\
\text { Compared to HA }(p<0.05)\end{array}$ \\
\hline 5 & $\begin{array}{l}\text { Zhao } \\
\text { et al. } \\
\text { (2013) }\end{array}$ & $\begin{array}{l}\text { In vitro study and Animal study } \\
\text { New Zealand White Rabbits ( } \\
=15 \text { ) }\end{array}$ & $\begin{array}{l}\text { 1. Screw titanium implants }(8 \times \\
4.1 \mathrm{~mm})(\mathrm{n}=30) 2 \text {. Titanium plates } \\
(25 \mathrm{~mm} \times 1.5 \mathrm{~mm})(\mathrm{n}=12) ;(10 \times 10 \times \\
1 \mathrm{~mm})(\mathrm{n}=72) \text { a. EDHA coating b. } \\
\text { EDMHA coating }\end{array}$ & $\begin{array}{l}\text { Pure hydroxyapatite (EDHA) or } \\
\text { Mg-substituted HA (EDMHA)- } \\
\text { Electrochemical deposition }\end{array}$ & $\begin{array}{l}\text { Bone implant contact }(\%) \\
\text { At } 2 \text { weeks } \\
\text { EDMHA group: } 61.77 \pm 8.53 \\
\text { EDHA } \\
44.17 \pm 12.35(p=0.086) \\
\text { Bone area }(\%) \\
\text { At } 2 \text { weeks } \\
\text { EDMHA group: } 40.30 \pm 10.67 \\
\text { EDHA } \\
38.39 \pm 23.25(p=0.831)\end{array}$ \\
\hline
\end{tabular}

adhesion and spreading on Mg-containing surfaces (Gorrieri et al., 2006; Jiang et al., 2014; Pardun et al., 2015; Won et al., 2017; Yu et al., 2017). The presence of actin filaments in spindle-shaped cells was suggestive of the migratory attitude of the osteoblasts. The polygonal shape with cytoplasmic processes enabled the cells to spread to reach larger sizes on the coating and they were found to 


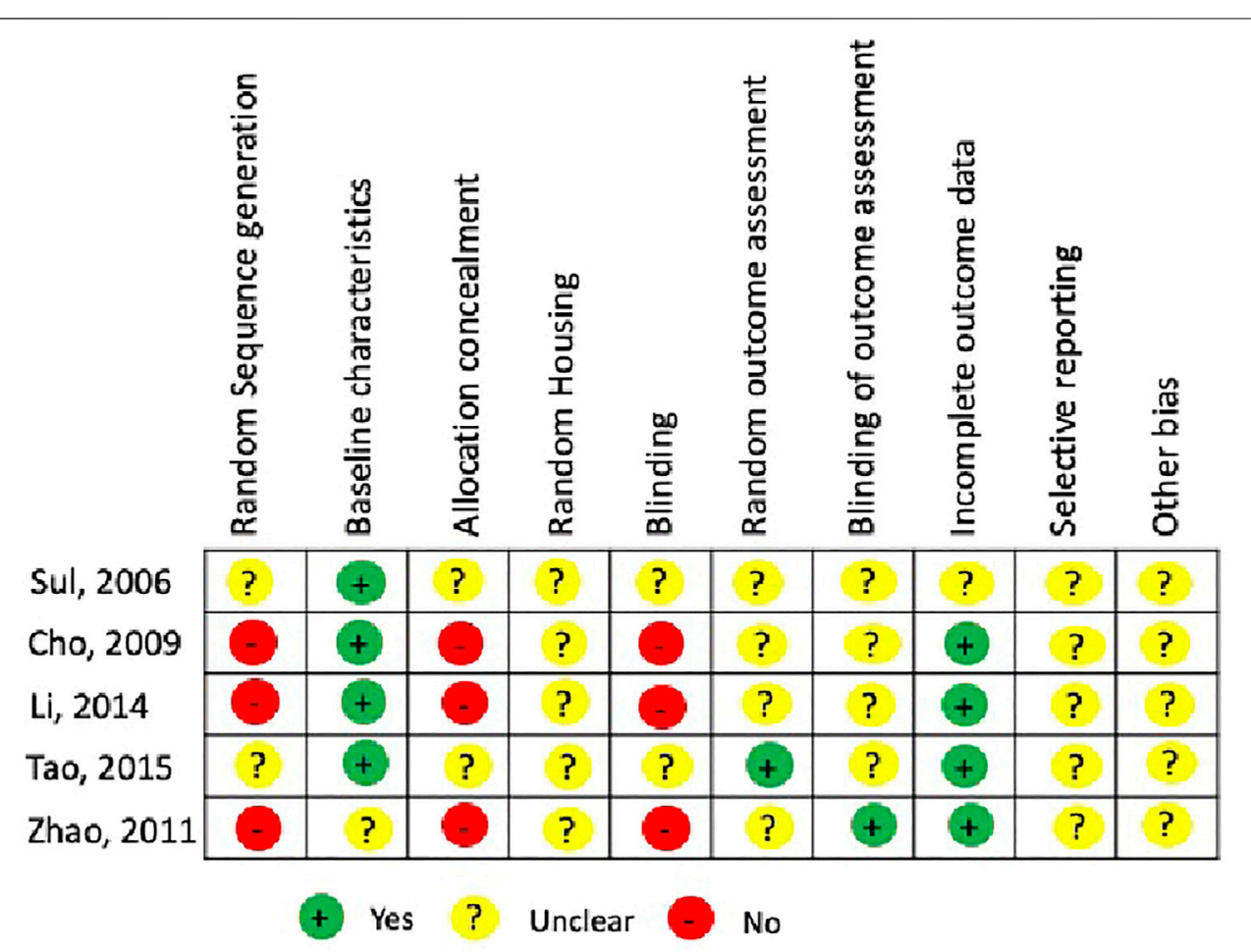

FIGURE 2 | Risk assessment using SYRCLE RoB tool for individual animal experimental studies included in the systematic review.

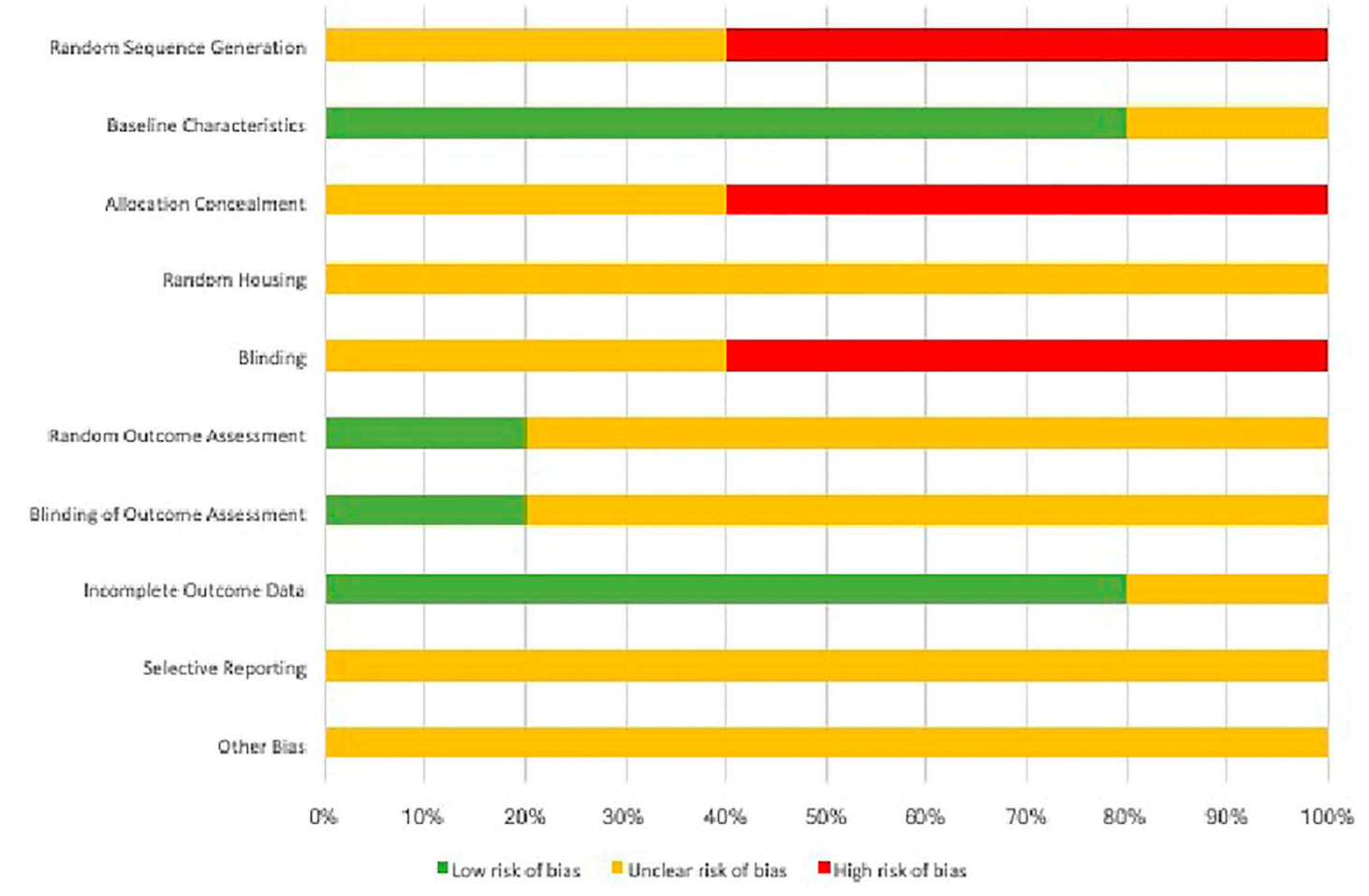

FIGURE 3 | Cumulative risk assessment of the included studies in the systematic review using individual items in SYRCLE RoB tool. 
be closely adherent to the coating (Gorrieri et al., 2006; Xie et al., 2009). Also, it was observed that there was increased cellular proliferation and cell viability with increased levels of osteogenic markers such as ALP, OCN, OPN, BSP, RUNX-2 etc influenced by the presence of $\mathrm{Mg}$ in the implant surface coating (Gorrieri et al., 2006; Jiang et al., 2014; Mihailescu et al., 2016; Onder et al., 2018; Pardun et al., 2015; Park et al., 2013; Won et al., 2017; Yu et al., 2017; Xie et al., 2009; Zhao et al., 2013). There was also increased deposition of Type-I collagen which is an essential component of the extracellular matrix and increased $\mathrm{Ca}$ deposition that can contribute to bone mineralization (Onder et al., 2018; Park et al., 2013; Won et al., 2017).

The success of dental implants is not only dependent on osseointegration but on the disruption of the microbial biofilm that can affect the health of the peri-implant tissues. Various organisms like Prevotella intermedia, Porphromonas gingivalis, Actinobacillus actinomycetemcomitans have been identified as etiological factors that can result in peri-implantitis where there is a pathological loss of peri-implant supporting tissues (Leonhardt et al., 1999; Schmidlin et al., 2013). This has warranted research towards newer and effective strategies on antibacterial surface coatings to prevent microbial adhesion and colonization on dental implants (Holban et al., 2014). Two studies in this systematic review observed the anti-bacterial effect of Mg-based coatings and there was significantly higher inhibitory effect with these coatings on microbes like P. gingivalis, F. nucleatum, S. mutans, Micrococcus sp, Enterococcus sp, and Candida albicans (Mihailescu et al., 2016; Yu et al., 2017). But, the results of the study conducted by Yu et al., suggested that the $\mathrm{Zn}$ portion of $\mathrm{Zn} / \mathrm{Mg}$ co-implanted surface could have contributed to the inhibitory effect because of $\mathrm{Zn}$ ions being established in the suppression of microbial adhesion and production of reactive oxygen species that are detrimental to the oral anaerobes (Yu et al., 2017). The study conducted by Mihailescu et al., suggested that BHA:MgO or BHA:MgF2 have anti-biofilm properties based on the hypothesis that these coatings exhibited bactericidal properties by killing cells during or after the contact with the coated surfaces (Mihailescu et al., 2016).

The potential limitation in this systematic review could be that the studies belong to the lower level of evidence (animal-model and in vitro design) and the quality assessment of the included studies revealed that there could be many potential sources of bias. The included studies had considerable heterogeneity and in most of the animal studies, the steps of randomization and blinding were not performed and some studies did not clearly explain the

\section{REFERENCES}

Albrektsson, T. (1998). Hard Tissue Response. Handbook of Biomaterial Properties. Boston, MA: Springer, 500-512. doi:10.1007/978-1-46155801-9_29

Albrektsson, T., and Wennerberg, A. (2004). Oral Implant Surfaces: Part 1-review Focusing on Topographic and Chemical Properties of Different Surfaces and In Vivo Responses to Them. Int. J. Prosthodont. 17 (5), 536-543.

Best, S. M., Porter, A. E., Thian, E. S., and Huang, J. (2008). Bioceramics: Past, Present and for the Future. J. Eur. Ceram. Soc. 28 (7), 1319-1327. doi:10.1016/ j.jeurceramsoc.2007.12.001 experimental protocol which is a potential confounding factor. The potential bias existing in these studies could have contributed to the positive outcomes obtained in it. There is a heterogeneity among the included studies in methodology, but the corresponding authors of the studies have been contacted for clarification or for providing any missing information relevant to performing to this review. Some disadvantages noted with $\mathrm{Mg}$ alloys include less corrosion resistance, lesser elastic modulus, but none has been identified yet with $\mathrm{Mg}$ coatings (Chakraborty Banerjee et al., 2019). But, from this systematic review, it is clear that there is a positive effect with Mg-based coatings on osteogenic activity and osseointegration in dental implants and these results could be ascertained as preliminary as the data was extracted mainly from in vitro and experimental animal models. However, future research should be targeted with more welldesigned and non-biased clinical studies that focus on confirming these lab-oriented results.

\section{CONCLUSION}

From this systematic review of literature, the results from the in vitro studies show that $\mathrm{Mg}$-based coatings improve the cellular behavior in terms of morphology and proliferation with increased expression of osteogenic markers and considerable antimicrobial activity. From the animal studies, it can be deduced that there was higher bone fill and BIC values with significant new bone formation. Even though the results are promising, there is considerable heterogeneity among the included studies, so clinical trials are warranted to provide compelling observations for outcomes that determine the long-term clinical success of dental implants.

\section{DATA AVAILABILITY STATEMENT}

The raw data supporting the conclusions of this article will be made available by the authors, without undue reservation.

\section{AUTHOR CONTRIBUTIONS}

Designing the search, analyzing the studies, analyzing results, writing manuscript and approval.

Boanini, E., Gazzano, M., and Bigi, A. (2010). Ionic Substitutions in Calcium Phosphates Synthesized at Low Temperature. Acta Biomater. 6 (6), 1882-1894. doi:10.1016/j.actbio.2009.12.041

Brohede, U., Zhao, S., Lindberg, F., Mihranyan, A., Forsgren, J., Strømme, M., et al. (2009). A Novel Graded Bioactive High Adhesion Implant Coating. Appl. Surf. Sci. 255 (17), 7723-7728. doi:10.1016/j.apsusc.2009.04.149

Castellani, C., Lindtner, R. A., Hausbrandt, P., Tschegg, E., Stanzl-Tschegg, S. E., Zanoni, G., et al. (2011). Bone-Implant Interface Strength and Osseointegration: Biodegradable Magnesium Alloy Versus Standard Titanium Control. Acta Biomater. 7 (1), 432-440. doi:10.1016/ j.actbio.2010.08.020

Cattani Lorente, M., Scherrer, S. S., Richard, J., Demellayer, R., Amez-Droz, M., and Wiskott, H. W. A. (2010). Surface Roughness and EDS Characterization of 
a Y-TZP Dental Ceramic Treated With the CoJet Sand. Dental Mater. 26 (11), 1035-1042. doi:10.1016/j.dental.2010.06.005

Chakraborty Banerjee, P., Al-Saadi, S., Choudhary, L., Harandi, S. E., and Singh, R. (2019). Magnesium Implants: Prospects and Challenges. Materials. 12 (1), 136. doi:10.3390/ma12010136

Cho, L-R., Kim, D-G., Kim, J-H., Byon, E-S., Jeong, Y-S., and Park, C-J. (2010). Bone Response of Mg Ion-Implanted Clinical Implants with the Plasma Source Ion Implantation Method. Clin. Oral Implants Res. 21, 848. doi:10.1111/j.16000501.2009.01862.x

Darimont, G. L., Cloots, R., Heinen, E., Seidel, L., and Legrand, R. (2002). In Vivo Behaviour of Hydroxyapatite Coatings on Titanium Implants: a Quantitative Study in the Rabbit. Biomaterials. 23 (12), 2569-2575. doi:10.1016/s01429612(01)00392-1

Gorrieri, O., Fini, M., Kyriakidou, K., Zizzi, A., Mattioli-Belmonte, M., Castaldo, P., et al. (2006). In Vitro Evaluation of Bio-Functional Performances of Ghimas Titanium Implants. Int. J. Artif. Organs. 29 (10), 1012-1020. doi:10.1177/ 039139880602901012

Hass, J. L., Garrison, E. M., Wicher, S. A., Knapp, B., Bridges, N., Mcllroy, D., et al. (2012). Synthetic Osteogenic Extracellular Matrix Formed by Coated Silicon Dioxide Nanosprings. J. Nanobiotechnology. 10 (1), 6. doi:10.1186/1477-315510-6

Hench, L. L. (2002). Third-Generation Biomedical Materials. Science. 295 (5557), 1014-1017. doi:10.1126/science.1067404

Holban, A.-M., Bleotu, C., Chifiriuc, M. C., Bezirtzoglou, E., and Lazar, V. (2014). Role ofPseudomonas Aeruginosaquorum Sensing (QS) Molecules on the Viability and Cytokine Profile of Human Mesenchymal Stem Cells. Virulence. 5 (2), 303-310. doi:10.4161/viru.27571

Hooijmans, C. R., Rovers, M. M., de Vries, R. B., Leenaars, M., Ritskes-Hoitinga, M., and Langendam, M. W. (2014). SYRCLE's Risk of Bias Tool for Animal Studies. BMC Med. Res. Methodol. 14 (1), 14-43. doi:10.1186/1471-2288$14-43$

Hoppe, A., Güldal, N. S., and Boccaccini, A. R. (2011). A Review of the Biological Response to Ionic Dissolution Products From Bioactive Glasses and GlassCeramics. Biomaterials. 32 (11), 2757-2774. doi:10.1016/ j.biomaterials.2011.01.004

Jemat, A., Ghazali, M. J., Razali, M., and Otsuka, Y. (2015). Surface Modifications and Their Effects on Titanium Dental Implants. Biomed. Res. Int. 2015, 1-11. doi:10.1155/2015/791725

Jiang, X., Wang, G., Li, J., Zhang, W., Xu, L., Pan, H., et al. (2014). Magnesium Ion Implantation on a Micro/Nanostructured Titanium Surface Promotes its Bioactivity and Osteogenic Differentiation Function. Int. J. Nanomedicine. 8, 2387. doi:10.2147/ijn.s58357

Jiang, X., Zhang, w., Li, z., Ling Xu, L., Yuqin Jin, Y., et al. (2013). Effects of a Hybrid Micro/nanorod Topography-Modified Titanium Implant on Adhesion and Osteogenic Differentiation in Rat Bone Marrow Mesenchymal Stem Cells. Int J Nanomedicine. 8, 257. doi:10.2147/ijn.s39357

Leonhardt, Å., Renvert, S., and Dahlén, G. (1999). Microbial Findings at Failing Implants. Clin. Oral Implants Res. 10 (5), 339-345. doi:10.1034/j.16000501.1999.100501.x

Li, X., Li, Y., Liao, Y., Li, J., Zhang, L., and Hu, J. (2014). The Effect of MagnesiumIncorporated Hydroxyapatite Coating on Titanium Implant Fixation in Ovariectomized Rats. Int. J. Oral Maxillofac. Implants. 29 (1), 196-202. doi:10.11607/jomi.2893

Liang, H., Wan, Y. Z., He, F., Huang, Y., Xu, J. D., Li, J. M., et al. (2007). Bioactivity of Mg-Ion-Implanted Zirconia and Titanium. Appl. Surf. Sci. 253 (6), 3326-3333. doi:10.1016/j.apsusc.2006.07.038

Lung, C. Y. K., and Matinlinna, J. P. (2012). Aspects of Silane Coupling Agents and Surface Conditioning in Dentistry: An Overview. Dental Mater. 28 (5), 467-477. doi:10.1016/j.dental.2012.02.009

Mihailescu, N., Stan, G. E., Duta, L., Chifiriuc, M. C., Bleotu, C., Sopronyi, M., et al. (2016). Structural, Compositional, Mechanical Characterization and Biological Assessment of Bovine-Derived Hydroxyapatite Coatings Reinforced With MgF 2 or $\mathrm{MgO}$ for Implants Functionalization. Mater. Sci. Eng. C. 59, 863-874. doi:10.1016/j.msec.2015.10.078

Niinomi, M. (2008). Mechanical Biocompatibilities of Titanium Alloys for Biomedical Applications. J. Mech. Behav. Biomed. Mater. 1 (1), 30-42. doi:10.1016/j.jmbbm.2007.07.001
Onder, S., Calikoglu-Koyuncu, A. C., Kazmanli, K., Urgen, M., Kok, F. N., and Torun-Kose, G. (2018). Magnesium Doping on TiN Coatings Affects Mesenchymal Stem Cell Differentiation and Proliferation Positively in a Dose-Dependent Manner. Biomed Mater Eng. 29 (4), 427-438. doi:10.3233/ bme- 181000

Pang, K.-M., Lee, J.-W., Lee, J.-Y., Lee, J.-B., Kim, S.-M., Kim, M.-J., et al. (2014). Clinical Outcomes of Magnesium-Incorporated Oxidised Implants: a Randomised Double-Blind Clinical Trial. Clin. Oral Impl. Res. 25 (5), 616-621. doi:10.1111/clr.12091

Pardun, K., Treccani, L., Volkmann, E., Streckbein, P., Heiss, C., Gerlach, J. W., et al. (2015). Magnesium-containing Mixed Coatings on Zirconia for Dental Implants: Mechanical Characterization and In Vitro Behavior. J. Biomater. Appl. 30 (1), 104-118. doi:10.1177/0885328215572428

Park, J.-W., Kim, H.-K., Kim, Y.-J., Jang, J.-H., Song, H., and Hanawa, T. (2010). Osteoblast Response and Osseointegration of a Ti-6Al-4V alloy Implant Incorporating Strontium. Acta Biomater. 6 (7), 2843-2851. doi:10.1016/ j.actbio.2010.01.017

Park, K.-D., Lee, B.-A., Piao, X.-H., Lee, K.-K., Park, S.-W., Oh, H.-K., et al. (2013). Effect of Magnesium and Calcium Phosphate Coatings on Osteoblastic Responses to the Titanium Surface. J. Adv. Prosthodont. 5 (4), 402. doi:10.4047/jap.2013.5.4.402

Revell, P., Damien, E., Zhang, X., Evans, P., and Howlett, C. (2004). The Effect of Magnesium Ions on Bone Bonding to Hydroxyapatite Coating on Titanium alloy Implants. Key Eng. Mat. 254, 447-450. 10.4028/www.scientific.net/KEM. 254-256.447.

Richards, D. (2009). GRADING - Levels of Evidence. Evid. Based Dent. 10 (1), 24-25. doi:10.1038/sj.ebd.6400636

Rude, R. K., Gruber, H. E., Norton, H. J., Wei, L. Y., Frausto, A., and Kilburn, J. (2006). Reduction of Dietary Magnesium by Only $50 \%$ in the Rat Disrupts Bone and Mineral Metabolism. Osteoporos. Int. 17 (7), 1022-1032. doi:10.1007/ s00198-006-0104-3

Sader, M. S., LeGeros, R. Z., and Soares, G. A. (2009). Human Osteoblasts Adhesion and Proliferation on Magnesium-Substituted Tricalcium Phosphate Dense Tablets. J. Mater. Sci. Mater. Med. 20 (2), 521-527. doi:10.1007/s10856-008-3610-3

Sawada, R., Kono, K., Isama, K., Haishima, Y., and Matsuoka, A. (2013). CalciumIncorporated Titanium Surfaces Influence the Osteogenic Differentiation of Human Mesenchymal Stem Cells. J. Biomed. Mater. Res. 101A (9), 2573-2585. doi:10.1002/jbm.a.34566

Schmidlin, P. R., Müller, P., Attin, T., Wieland, M., Hofer, D., and Guggenheim, B. (2013). Polyspecies Biofilm Formation on Implant Surfaces With Different Surface Characteristics. J. Appl. Oral Sci. 21 (1), 48-55. doi:10.1590/16787757201302312

Shi, X., Nakagawa, M., Kawachi, G., Xu, L., and Ishikawa, K. (2012). Surface Modification of Titanium by Hydrothermal Treatment in Mg-Containing Solution and Early Osteoblast Responses. J. Mater. Sci. Mater. Med. 23 (5), 1281-1290. doi:10.1007/s10856-012-4596-4

Staiger, M. P., Pietak, A. M., Huadmai, J., and Dias, G. (2006). Magnesium and its Alloys as Orthopedic Biomaterials: A Review. Biomaterials. 27 (9), 1728-1734. doi:10.1016/j.biomaterials.2005.10.003

Stanford, C. (2008). Surface Modifications of Dental Implants. Aust. Dental J. 53 (s1), S26-S33. doi:10.1111/j.1834-7819.2008.00038.x

Sul, Y.-T., Jeong, Y., Johansson, C., and Albrektsson, T. (2006). Oxidized, Bioactive Implants Are Rapidly and Strongly Integrated in Bone. Part 1 - Experimental Implants. Clin. Oral Implants Res. 17 (5), 521-526. doi:10.1111/j.16000501.2005.01230.x

Tao, Z.-S., Zhou, W.-S., He, X.-W., Liu, W., Bai, B.-L., Zhou, Q., et al. (2016). A Comparative Study of Zinc, Magnesium, Strontium-Incorporated Hydroxyapatite-Coated Titanium Implants for Osseointegration of Osteopenic Rats. Mater. Sci. Eng. C. 62, 226-232. doi:10.1016/ j.msec.2016.01.034

Tschernitschek, H., Borchers, L., and Geurtsen, W. (2005). Nonalloyed Titanium as a Bioinert Metal-Aa Review. Quintessence Int. 36 (7-8), 523-530.

Won, S., Huh, Y.-H., Cho, L.-R., Lee, H.-S., Byon, E.-S., and Park, C. J. (2017). Cellular Response of Human Bone Marrow Derived Mesenchymal Stem Cells to Titanium Surfaces Implanted With Calcium and Magnesium Ions. Tissue Eng. Regen. Med. 14 (2), 123-131. doi:10.1007/s13770-017-0028-3 
Xie, Y., Zhai, W., Chen, L., Chang, J., Zheng, X., and Ding, C. (2009). Preparation and In Vitro Evaluation of Plasma-Sprayed Mg2SiO4 Coating on Titanium alloy. Acta Biomater. 5 (6), 2331-2337. doi:10.1016/j.actbio.2009.03.003

Yamasaki, Y., Yoshida, Y., Okazaki, M., Shimazu, A., Uchida, T., Kubo, T., et al. (2002). Synthesis of Functionally Graded MgCO3 Apatite Accelerating Osteoblast Adhesion. J. Biomed. Mater. Res. 62 (1), 99-105. doi:10.1002/ jbm.10220

Ying Kei Lung, C. (2017). Surface Coatings of Titanium and Zirconia. Adv. Mater. Sci. [Internet] 2 (2), 1. doi:10.15761/ams.1000124

Yu, J., Li, K., Zheng, X., He, D., Ye, X., and Wang, M. (2013). In Vitro and In Vivo Evaluation of Zinc-Modified Ca-Si-Based Ceramic Coating for Bone Implants. PLoS ONE. 8 (3), e57564. doi:10.1371/journal.pone.0057564

Yu, Y., Ding, T., Xue, Y., and Sun, J. (2016). Osteoinduction and Long-Term Osseointegration Promoted by Combined Effects of Nitrogen and Manganese Elements in High Nitrogen Nickel-Free Stainless Steel. J. Mater. Chem. B. 4 (4), 801-812. doi:10.1039/c5tb02190a

Yu, Y., Jin, G., Xue, Y., Wang, D., Liu, X., and Sun, J. (2017). Multifunctions of Dual $\mathrm{Zn} / \mathrm{Mg}$ Ion Co-Implanted Titanium on Osteogenesis, Angiogenesis and Bacteria Inhibition for Dental Implants. Acta Biomater. 49, 590-603. doi:10.1016/j.actbio.2016.11.067

Zhao, S.-f., Jiang, Q.-h., Peel, S., Wang, X.-x., and He, F. m. (2013). Effects of Magnesium-Substituted Nanohydroxyapatite Coating on Implant Osseointegration. Clin. Oral Impl. Res. 24, 34-41. doi:10.1111/j.16000501.2011.02362.x
Zhou, Y., Jiang, T., Qian, M., Zhang, X., Wang, J., Shi, B., et al. (2008). Roles of Bone Scintigraphy and Resonance Frequency Analysis in Evaluating Osseointegration of Endosseous Implant. Biomaterials. 29 (4), 461-474. doi:10.1016/j.biomaterials.2007.10.021

Zreiqat, H., Howlett, C. R., Zannettino, A., Evans, P., Schulze-Tanzil, G., Knabe, C., et al. (2002). Mechanisms of Magnesium-Stimulated Adhesion of Osteoblastic Cells to Commonly Used Orthopaedic Implants. J. Biomed. Mater. Res. 62 (2), 175-184. doi:10.1002/jbm.10270

Conflict of Interest: The author declares that the research was conducted in the absence of any commercial or financial relationships that could be construed as a potential conflict of interest.

Publisher's Note: All claims expressed in this article are solely those of the authors and do not necessarily represent those of their affiliated organizations, or those of the publisher, the editors and the reviewers. Any product that may be evaluated in this article, or claim that may be made by its manufacturer, is not guaranteed or endorsed by the publisher.

Copyright (C) 2021 Almehmadi. This is an open-access article distributed under the terms of the Creative Commons Attribution License (CC BY). The use, distribution or reproduction in other forums is permitted, provided the original author $(s)$ and the copyright owner(s) are credited and that the original publication in this journal is cited, in accordance with accepted academic practice. No use, distribution or reproduction is permitted which does not comply with these terms. 